\title{
A DNA method for screening hive debris for the presence of small hive beetle (Aethina tumida)*
}

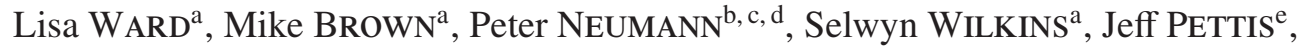 \\ Neil BOONHAM ${ }^{\mathrm{a}}$ \\ ${ }^{a}$ Central Science Laboratory, Sand Hutton, York, YO41 1LZ, England \\ b Institut für Zoologie, Martin-Luther-Universität Halle-Wittenberg, Hoher Weg 4, 06099 Halle (Saale), Germany \\ ${ }^{\mathrm{c}}$ Department of Zoology and Entomology, Rhodes University, 61440 Grahamstown, South Africa \\ ${ }^{\mathrm{d}}$ Eastern Bee research Institute of Yunnan Agricultural University, Heilongtan, Kunming, \\ Yunnan Province, China

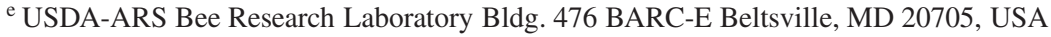

Received 17 April 2006 - Revised 9 October 2006 - Accepted 23 October 2006

\begin{abstract}
The small hive beetle (SHB) is a parasite and scavenger of honey bee colonies. It has recently become an invasive species creating the need for an efficient and reliable detection method. We present a method to screen hive debris for the presence of SHB using real-time PCR in conjunction with an automated DNA extraction protocol. The method was able to detect DNA from SHB eggs, larvae and adult specimens collected from Africa, Australia and North America. The method was used to successfully detect SHB DNA extracted from spiked and naturally infested debris. An Apis mellifera 18S rRNA real-time PCR assay was used as an internal positive control (IPC). The IPC showed that the method was reliable for detection as extraction efficiency was consistent between hive debris samples. If the SHB were to establish at new locations, the availability of such a method would be a valuable support tool to enable species identification and rapid screening of hive debris for delimiting surveys.
\end{abstract}

Aethina tumida / real-time PCR / honey bee / small hive beetle / hive debris

\section{INTRODUCTION}

The small hive beetle, (Aethina tumida Murray: Coleoptera, Nitidulidae, = SHB), is a minor pest of African honey bee colonies (Neumann and Elzen, 2004; Neumann and Härtel, 2004), that has recently become a harmful invasive species (Hood, 2004; Neumann and Elzen, 2004; Ellis and Hepburn, 2006). The beetle has attainted pest status in around 30 states in North America (Hood, 2004) where the economic impact on the Apiculture industry has been significant (Taber and Hood, 2000; Neumann and Elzen, 2004;

Corresponding author: N. Boonham,

n.boonham@csl.gov.uk

* Manuscript editor: Stefan Fuchs
Hood, 2004; Ellis, 2005; Harman, 2005). The beetle has now been reported in Canada (Hood, 2004) and Australia (White, 2004). It is anticipated that a similar scale of impact is likely to occur if the beetle establishes in other areas of the world with suitable climatic conditions.

There is currently a lack of molecular techniques for rapid detection and identification of the SHB. In particular, the eggs and larvae are difficult to detect and identify by morphological techniques alone (Murihas, 2004). In addition, there has been little focus on developing methods for detection of SHB at low (cryptic) levels of reproduction within a hive, where an overt infestation (which is readily identified on hive inspection) is not evident (Spiewok and Neumanm, 2006). 
The objective of this research was to develop a fast extraction protocol in conjunction with a real-time PCR assay to enable rapid identification of the SHB life stages, as well as screening of hive debris for detection of SHB - the method may be a valuable tool to test the many thousands of hive samples that might be submitted for laboratory diagnosis in the event of an incursion. The method could also have further value for routine surveillance of hives in high-risk areas such as those close to major ports, or where climatic conditions may be more conducive for establishment of the beetle.

\section{MATERIALS AND METHODS}

\subsection{DNA extraction from SHB beetle, larval and egg samples}

DNA was extracted using a modification of the 'DNA purification system for food' kit (Promega, Southampton, UK) as follows; the magnetic particles were manipulated using a robotic magnetic particle processor and the 'total genomic DNA programme' (Kingfisher $\mathrm{mL}$, Thermo Labsystems). SHB adult or larval tissue ( 100 mg) or eggs (1015 ), were placed in $2 \mathrm{~mL}$ micro-centrifuge tubes containing approximately $700 \mathrm{mg}$ of 2.4 or $1.0 \mathrm{~mm}$ Zirconia beads (Biospec Products, Bartlesville, Oklahoma, USA) and $1 \mathrm{~mL}$ of Wizard ${ }^{\circledR}$ MagneSil $^{\mathrm{TM}}$ extraction buffer A containing 1\% antifoam B (Sigma). The tubes were shaken for $30 \mathrm{~s}$ at full speed on a mini bead-beater, and then centrifuged at $10000 \mathrm{~g}$ for $2 \mathrm{~min}$. Clarified extract $(1 \mathrm{~mL})$ was transferred to a fresh $2 \mathrm{~mL}$ micro-centrifuge tube and $250 \mu \mathrm{L}$ of lysis buffer B (Promega) and $750 \mu \mathrm{L}$ of precipitation buffer (Promega) were added. After vortexing, tubes were spun at $10000 \mathrm{~g}$ for $10 \mathrm{~min}$. Clarified extract $(750 \mu \mathrm{L})$ was transferred to a fresh micro-centrifuge tube and $50 \mu \mathrm{L}$ of kit MagneSil ${ }^{\mathrm{TM}}$ beads and $600 \mu \mathrm{L}$ of isopropanol was added. Tubes were incubated at room temperature for $10 \mathrm{~min}$. The Kingfisher ML 5 tube strips were loaded as follows: tube 1: $1.4 \mathrm{~mL}$ of the sample containing the MagneSil ${ }^{\mathrm{TM}}$ beads; tube 2: $1 \mathrm{~mL}$ of kit lysis buffer B; tubes 3 and $4: 1 \mathrm{~mL}$ of $70 \%$ ethanol; tube 5: $100 \mu \mathrm{L} 1 \times$ TE buffer. DNA collected in tube 5 was transferred to a fresh $1.5 \mathrm{~mL}$ micro-centrifuge tube and stored at $-20{ }^{\circ} \mathrm{C}$ prior to use in real-time (TaqMan) PCR.

\subsection{DNA extraction from hive debris samples}

DNA was extracted from hive debris samples by placing $10 \mathrm{~g}$ samples of debris into grinding mill canisters (Kleco, Visalia, California, USA). CTAB (Hexadecyltrimethylammoniumbromide, [Sigma]) lysis buffer (12\% Sodium phosphate buffer $\mathrm{pH}$ 8.0, $2 \%$ CTAB, $1.5 \mathrm{M} \mathrm{NaCl}),(20 \mathrm{~mL})$ containing $1 \%$ antifoam B (Sigma) was added to each canister. The canisters were sealed, loaded onto the Kleco grinding mill and ground for $2 \mathrm{~min}$ at top speed. The lysate from each canister was poured into a $50 \mathrm{~mL}$ Falcon tube and the tubes were spun at $4000 \mathrm{~g}$ for $5 \mathrm{~min} ; 2 \mathrm{~mL}$ of the cleared lysate was removed and placed into a $2 \mathrm{~mL}$ micro-centrifuge tube. The tubes were spun for a further $3 \mathrm{~min}$ at $10000 \mathrm{~g}$. Cleared lysate $(1 \mathrm{~mL})$ was transferred to a fresh $2 \mathrm{~mL}$ micro-centrifuge tube and $250 \mu \mathrm{L}$ of lysis buffer B (Promega) and $750 \mu \mathrm{L}$ of precipitation buffer (Promega) were added. After vortexing, tubes were spun at $10000 \mathrm{~g}$ for $10 \mathrm{~min}$. Clarified extract (750 $\mu \mathrm{L}$ ) was transferred to a fresh micro-centrifuge tube and $50 \mu \mathrm{L}$ of kit MagneSil ${ }^{\mathrm{TM}}$ beads and $600 \mu \mathrm{L}$ of isopropanol was added. Tubes were incubated at Room temperature for $10 \mathrm{~min}$. DNA was extracted from each sample using the robotic magnetic particle processor (Kingfisher mL, Thermo Labsystems) in conjunction with the Promega DNA purification system for food kit as described previously for the beetle/larval extractions.

\subsection{Validation of a method to screen hive debris for the presence of the SHB}

\subsubsection{SHB detection in spiked hive debris}

To determine how much beetle or larval tissue was being spiked into hive debris material, 10 adult SHB and 10 larvae (Stellenbosch, South Africa) were weighed separately to obtain an average weight for each life stage. In addition, 10 adults and 10 larvae were cut in half and a half segment from each sample was weighed separately to obtain an average weight for each.

Hive debris was collected from the Central Science Laboratory apiaries during the spring and summer when the colonies were active. Samples of debris $(30 \mathrm{~g})$ were weighed out and spiked with $1 / 2$, 1, 2, 3 or 4 A. tumida adults (Stellenbosch, South Africa). Prior to spiking the debris, the beetles were 
cut into small $(\sim 2 \mathrm{~mm})$ size pieces using a sterile scalpel. The beetle pieces were thoroughly mixed into each $30 \mathrm{~g}$ debris sample. Each sample of spiked hive debris was then split into three $10 \mathrm{~g}$ replicates. DNA was extracted from each $10 \mathrm{~g}$ sample as described previously.

The experiment was repeated using 1/2, 1, 2, 3 and 4, Aethina tumida larvae. (The larvae were added whole to the debris samples). Positive controls were included for both experiments as $1 / 2,1,2$, 3 and 4 beetles or larvae ground in $20 \mathrm{~mL}$ of CTAB lysis buffer without hive debris. Negative controls were included as unspiked hive debris ground in $20 \mathrm{~mL}$ of CTAB buffer and CTAB buffer only. The DNA was extracted as previously described, and tested using the SHB CO1 and bee 18S rRNA realtime PCR assays.

\subsubsection{Detection of A. tumida in debris from infested hives}

Debris was collected from a hive naturally infested with SHB in Beltsville, Maryland USA. Three $10 \mathrm{~g}$ replicate samples of debris were weighed out and placed in Kleco grinding mill canisters and ground for $2 \mathrm{~min}$ as described previously. DNA was extracted from 3 replicate $1 \mathrm{~mL}$ samples of cleared lysate as described previously. Final DNA extracts were tested neat and after diluting 1 in 10 in molecular grade water (BDH, Lutterworth, Leicestershire, UK) using the SHB CO1 and bee $18 \mathrm{~S}$ rRNA real-time PCR assays.

\subsection{4 Design of a real-time (TaqMan ${ }^{\circledR}$ ) PCR for the detection of A. tumida}

Real-time PCR primers SHB207F - TCTAAATACTACTTTCTTCGACCCATC(A/G), SHB315R - TCCTGGTAGAATTAAAATATAAACTTCTGG and a probe SHB245T - ATCCAATCCTATACCAACACTTATTTTGATTCTTCGGAC were designed to the A. tumida cytochrome oxidase I gene (COI) from mitochondrial DNA using Primer Express $^{\mathrm{TM}}$ software (PE-Biosystems). All 15 COI sequences available for A. tumida (Accession numbers AF227645-AF227654, AF522354-AF522358), were obtained from the EMBL sequence database and aligned using clustal $\mathrm{V}$ within the MegAlign package (DNASTAR INC., Madison, USA). In order to allow detection of the two haplotypes identified by these sequences, the forward primer was designed with degeneracy at nucleotide position 228 (AF227645). The fluorogenic probe was modified at the 3' end with a quencher dye TAMRA (tetramethylcarboxyrhodamine, Applied Biosystems) and at the 5 ' end with the fluorescent reporter dye FAM (6-carboxyfluorescein, Applied Biosystems).

A real-time PCR assay previously designed to the 18S rRNA gene of A. mellifera (Ward et al., 2007), was used in addition to the SHB primer in order to determine if this assay could be used as an internal positive control (IPC). An IPC is used to assess the efficiency of nucleic acid extraction and to verify false negative results. The bee $18 \mathrm{~S}$ probe was labeled at the 3' and 5' ends as described previously for the SHB probe.

The real-time SHB assay was validated using DNA extracted from different life stages (eggs, larvae and adults) of A. tumida. Adults and larvae were obtained from infested hives from various locations: Australia (Queensland and Richmond, New South Wales), South Africa (Grahamstown, Heidelburg, Ixopo, Pretoria, Port Elizabeth and Stellenbosch) and North America (Maryland, Louisiana and Florida).

The real-time PCR assay was checked for general cross-reaction with DNA extracted from Apis mellifera $\mathrm{L}$. and from a range of insect species collected inside (and around) honey bee hives (Tab. I). DNA from the bee mites Varroa destructor Anderson and Trueman (Acari: Varroidae) and Tropilaelaps spp. (Acari: Laelapidae) were included in the cross-reaction. All specimens were stored in $70 \%$ ethanol before use.

\subsection{Real-time $\left(\operatorname{TaqMan}^{\circledR}\right) \mathrm{PCR}$ reactions}

All real-time $\left(\mathrm{TaqMan}^{\circledR}\right)$ reactions were set up as duplicate wells using Stratagene Brilliant core reagents (Stratagene, La Jolla, California, USA) according to the manufacturer's protocols. For each reaction, $1 \mu \mathrm{L}$ DNA was added to $24 \mu \mathrm{L}$ of mastermix in the appropriate well. Primers and probe concentrations were $300 \mathrm{nM}$ and $200 \mathrm{nM}$ respectively per $25 \mu \mathrm{L}$ reaction. Plates were cycled at generic system conditions $\left(50{ }^{\circ} \mathrm{C}\right.$ for $2 \mathrm{~min}, 95{ }^{\circ} \mathrm{C}$ for 10 min and 40 cycles of $60{ }^{\circ} \mathrm{C}$ for 1 min plus $95^{\circ} \mathrm{C}$ for $15 \mathrm{~s}$ ) within the 7900 Sequence Detection System (Applied Biosystems, Branchburg, New Jersey, USA) using real-time data collection. Realtime PCR data is expressed as $C_{T}$ (cycle threshold) 
Table I. Average Ct values (for 3 replicate $100 \mathrm{mg}$ tissue samples or 10-15 SHB eggs \pm standard deviation) for the detection of DNA (CO1 gene) from A. tumida collected from different geographical locations. Results are also shown for other insect species (individual insects) and bee mites used in cross-reaction tests.

\begin{tabular}{|c|c|c|c|c|}
\hline Species & Family & Sampling localities & Life stage & $\begin{array}{l}\text { Average } \\
\text { Ct value }\end{array}$ \\
\hline A tumida & Nitidulidae & Heidelburg, South Africa, & Adult & $20.77 \pm 0.13$ \\
\hline A. tumida & “ & Ixopo, South Africa & Adult & $24.48 \pm 0.18$ \\
\hline A. tumida & “ & Port Elizabeth, South Africa & Adult & $22.31 \pm 0.01$ \\
\hline A. tumida & “ & Grahamstown, South Africa & Adult & $22.47 \pm 0.04$ \\
\hline A. tumida & “ & Pretoria, South Africa & Adult & $22.87 \pm 0.09$ \\
\hline A. tumida & “ & Stellenbosch, South Africa & Adult & $25.21 \pm 0.13$ \\
\hline A. tumida & “ & Beltsville, USA & Adult & $23.72 \pm 0.03$ \\
\hline A. tumida & “ & Louisiana, USA & Adult & $21.66 \pm 0.06$ \\
\hline A. tumida & “ & Florida, USA & Adult & $22.66 \pm 0.23$ \\
\hline A. tumida & “ & Queensland, Australia & Adult & $26.19 \pm 0.06$ \\
\hline A. tumida & “ & Richmond, NSW, Australia & Adult & $22.17 \pm 0.08$ \\
\hline A. tumida & “ & Stellenbosch, South Africa & Larvae & $28.56 \pm 0.31$ \\
\hline A. tumida & “ & Florida, USA & Larvae & $26.45 \pm 0.19$ \\
\hline A. tumida & “ & Beltsville, USA & Larvae & $22.56 \pm 0.06$ \\
\hline A. tumida & “ & Beltsville, USA & Eggs & $19.68 \pm 1.41$ \\
\hline Dorcus parallelopipdus & Lucanidae & UK & Adult & Negative \\
\hline Agabus bipustulatus & Dytiscidae & UK & Adult & Negative \\
\hline Antherophagus nigricornis & Cryptophagidae & UK & Adult & Negative \\
\hline Melgethes rotundicollis & Nitidulidae & UK & Adult & Negative \\
\hline $\begin{array}{l}\text { Bombus } \\
\text { (species uknown) }\end{array}$ & Apidae & UK & Adult & Negative \\
\hline Pterostichus spp. & Carabidae & UK & Adult & Negative \\
\hline Otiorhynchus claviceps & Curculionoidea & UK & Adult & Negative \\
\hline Glischrochilus hortensis & Nitidulidae & UK & Adult & Negative \\
\hline Apis mellifera & Apidae & UK & Adult & Negative \\
\hline Varroa destructor & Varroidae & UK & Adult & Negative \\
\hline Tropilaelaps spp. & Laelapidae & Chiang mai, Thailand & Adult & Negative \\
\hline
\end{tabular}

values. This is the PCR cycle at which PCR products are first detected above a baseline threshold.

\subsection{Cloning and sequencing of real-time PCR products}

Real-time PCR products $(2 \mu \mathrm{L})$ were directly ligated into plasmid pGEM $^{\circledR}$-T Easy Vector (Promega, Madison, USA), and transformed into E. coli JM109 High Efficiency competent cells (Promega, Madison, USA) following the manufacturer's protocols. White bacterial colonies containing plasmids with inserts were selected and plasmid DNA was purified using the Wizard ${ }^{\circledR}$ Plus SV miniprep DNA purification system (Promega, Madison, USA). Purified plasmid concentrations were adjusted to $20 \mathrm{ng} \mu \mathrm{L}^{-1}$ for sequencing. Sequencing was carried out by the DNAseq sequencing service, University of Dundee, Scotland. 
Table II. Average $C_{T}$ values for the detection of $A$. tumida CO1 and bee $18 \mathrm{~s}$ (IPC) in spiked spring/summer debris (the results show the average values \pm standard deviation for 3 replicate samples for each treatment). Positive controls are beetles and larvae ground in an equivalent amount of lysis buffer without hive debris.

\begin{tabular}{llll}
\hline Replicate/Sample & $\begin{array}{l}\text { Average } C_{T} \text { value } \\
\text { A. tumida }\end{array}$ & Average $C_{T}$ value Bee IPC & $\begin{array}{l}\text { Average } C_{T} \text { value } \\
\text { Positive controls }\end{array}$ \\
\hline Unspiked debris & $40.00 \pm 0.00$ & $15.45 \pm 0.01$ & - \\
CTAB only buffer control & $40.00 \pm 0.00$ & $40.00 \pm 0.00$ & - \\
1/2 beetle & $40.00 \pm 0.00$ & $15.63 \pm 0.04$ & $24.70 \pm 0.01$ \\
1 beetle & $38.36 \pm 0.14$ & $15.67 \pm 0.01$ & $23.32 \pm 0.05$ \\
2 beetle & $26.22 \pm 0.04$ & $15.36 \pm 0.01$ & $23.58 \pm 0.24$ \\
3 beetle & $25.43 \pm 0.26$ & $14.96 \pm 0.08$ & $23.50 \pm 0.08$ \\
4 beetle & $23.81 \pm 0.07$ & $14.96 \pm 0.08$ & $23.40 \pm 0.09$ \\
1/2 larvae & $35.32 \pm 0.00(1 / 3)^{*}$ & $14.98 \pm 0.03$ & $28.09 \pm 1.08$ \\
1 larvae & $36.24 \pm 0.29(1 / 3)^{*}$ & $15.73 \pm 0.01$ & $26.46 \pm 0.15$ \\
2 larvae & $31.66 \pm 0.13(2 / 3)^{*}$ & $15.47 \pm 0.03$ & $24.71 \pm 0.21$ \\
3 larvae & $29.74 \pm 0.28(2 / 3)^{*}$ & $15.52 \pm 0.04$ & $23.74 \pm 0.23$ \\
4 larvae & $30.27 \pm 0.12(2 / 3)^{*}$ & $15.08 \pm 0.01$ & $23.54 \pm 0.13$ \\
\hline
\end{tabular}

(-) Indicates data not collected. * Indicates number of positive replicates.

\section{RESULTS}

\subsection{Real-time PCR primers and probes}

The sequence for the SHB COI realtime PCR product (109 bp) was compared to sequences on the NCBI sequence database using a BLAST search (http://www.ncbi.nlm.gov/BLAST) to identify homologous sequences. The amplicon sequence matched all $15 \mathrm{COI}$ sequences available on the database for A. tumida. (Accession numbers AF227645-AF227654, AF522354AF522358) confirming the real-time PCR product to be A. tumida .

\subsection{Validation of the SHB real-time (TaqMan ${ }^{\circledR}$ ) PCR assay}

The SHB real-time primers and probe were validated using DNA extracted from SHB adults, larvae and eggs collected from various geographical locations. The real-time PCR assay was able to detect all life stages and all beetles from the different geographical locations. In addition, no cross-reaction was observed when the primers were tested with
DNA extracted from a range of insects including A. mellifera and from the bee mites, Varroa destructor and Tropilaelaps clareae. (Tab. I).

\subsection{Detection of the SHB in spiked hive debris}

SHB DNA could be detected in all hive debris samples spiked with adult beetles, with the exception of half a beetle. This would suggest that the sensitivity of the current assay is limited to detecting approximately $17.28 \pm$ $2.84 \mathrm{mg}$ of SHB tissue (one beetle) in $30 \mathrm{~g}$ of hive debris. For both beetle and larval spikes, the $C_{T}$ values decreased (i.e. DNA levels increasing) with increasing amounts of SHB tissue spiked in the debris. The exception to this was the four larvae spike. In this instance, the $C_{T}$ value rose slightly ( $\left.C_{T} 30.27\right)$ in comparison to the three larvae spike $\left(C_{T}\right.$ 29.74) (Tab. II). The number of positives out of 3 varied for the larval samples, however, as the larvae were added whole to the debris, this would reflect the grouping of more than one larva in certain replicates and none in others. When the TaqMan $C_{T}$ values for $A$. tumida detection were plotted against the number of 
Table III. Average $C_{T}$ values for the detection of $A$. tumida $\mathrm{CO} 1$ and bee $18 \mathrm{~s}$ (IPC) in debris collected from SHB infested hives from the USA. The results show the average values \pm standard deviation for 3 replicates.

\begin{tabular}{llll}
\hline $\begin{array}{l}\text { Sample number } \\
(10 \text { g hive debris })\end{array}$ & Extraction replicate number & $\begin{array}{l}\text { Average } C_{T} \text { value } \\
\text { A. tumida }\end{array}$ & $\begin{array}{l}\text { Average } C_{T} \text { value } \\
\text { Bee IPC }\end{array}$ \\
\hline \multirow{3}{*}{1} & 1 & $28.66 \pm 0.52$ & $22.29 \pm 0.11$ \\
& 2 & $30.66 \pm 0.10$ & $23.91 \pm 0.35$ \\
& 3 & $28.96 \pm 0.18$ & $22.37 \pm 0.06$ \\
2 & 1 & $29.51 \pm 0.13$ & $22.05 \pm 0.39$ \\
& 2 & $33.11 \pm 0.38$ & $24.21 \pm 0.11$ \\
3 & 3 & $30.00 \pm 0.62$ & $21.99 \pm 0.28$ \\
& 1 & $28.51 \pm 0.43$ & $22.88 \pm 0.16$ \\
& 2 & $32.02 \pm 1.01$ & $28.75 \pm 0.28$ \\
\end{tabular}

beetles or larvae spiked into the hive debris, a good correlation was observed, indicated by a straight line where the $\mathrm{R}$ value was 0.84 for both beetle and larvae spikes.

TaqMan $C_{T}$ values for $A$. tumida detection in spiked debris were higher than the control samples with no hive debris. $C_{T}$ values for hive debris spiked with larvae were 7 to $10 \mathrm{cy}-$ cles lower in comparison to the control samples (100 to 1000 fold decrease in sensitivity). For the hive debris samples spiked with beetles, the decrease in sensitivity was more variable. A difference of 1 to 15 cycles was observed ( 3.3 to a $10^{4}$ fold decrease in detection sensitivity).

DNA extracts from the debris samples were tested with the bee IPC assay. The $C_{T}$ values for the extracts averaged $15.39 \pm 0.28$ for the beetle spikes and $15.36 \pm 0.31$ for the larval spikes (Tab. II).

\subsection{Detection of $A$. tumida in naturally infested hive debris}

A. tumida was successfully detected in all three replicate samples of naturally infested hive debris. The bee IPC was also successfully detected in all three replicates. The average TaqMan $C_{T}$ values for three replicate samples of hive debris was $29.69 \pm 2.55$ and $23.71 \pm 2.08$ for $A$. tumida and the bee IPC respectively (Tab. III).

\section{DISCUSSION}

To date there have been few molecular studies on the SHB and no published PCR detection assays currently exist. In this study, real-time $\left(\right.$ TaqMan $\left.^{\circledR}\right)$ PCR was used successfully in conjunction with an automated DNA extraction protocol to enable species identification and detection of SHB in hive debris. The methods developed are particularly suited for high-throughput diagnostic work. Using the automated extraction protocol, DNA can be extracted from up to 96 samples within 1 hour. Real-time PCR has several advantages over conventional PCR, no post-PCR manipulations are required and many samples can be analysed simultaneously, for example, 96 samples can be tested on most available instruments within a 2 hour period, giving a total throughput of 96 samples every three hours. More elaborate instruments are also available allowing 384 samples to be tested by real-time PCR within the 2 hour period. Although the equipment is potentially expensive, the cost has dropped 10 fold in the last 5 years. The savings in time, reagents and equipment as a result of removing gel running and interpretation of results from gel photographs, has resulted in a lower per-assay cost when compared to conventional PCR. This has caused a proliferation in the availability of real-time PCR equipment in routine diagnostic laboratories and a subsequent replacement of conventional PCR techniques. 
In our study, the real-time primers and probe were designed to sequence within the $\mathrm{COI}$ gene, and with degeneracy in the forward primer to allow detection of the two haplotypes for which sequence is available on the EMBL sequence database (Evans et al., 2000, 2002, 2003). The primers were shown to be specific for SHB as no cross-reaction was observed with DNA extracted from nine genera of insects (some insects being from the same family as the SHB), or with DNA from Varroa and Tropilaelaps mites that may form part of the hive debris in mite infested bee colonies. The results suggest that the real-time assay would be reliable for screening hive debris for the presence of the SHB.

The assay was successful in amplifying DNA extracted from egg, larval and adult life stages of the SHB and from beetle specimens collected from different geographical regions. These results suggest that the SHB assay should be able to detect new incursions or low-level infestations regardless of where the invading beetle/larvae/eggs originate from. However, the endemic distribution of SHB in sub-Saharan Africa is vast (Hepburn and Radloff, 1998; Neumann and Elzen, 2004), and new sequence data may emerge in light of molecular studies on SHB populations. In this instance the SHB primer and probe may require further testing to determine their detection capabilities.

A. tumida can be present at low (cryptic) levels (Spiewok and Neumann, 2006) within bee hives rather than as overt infestations (Lundie, 1940). Our experiments showed that it was possible to detect small fragments of a single beetle in a starting volume of $30 \mathrm{~g}$ of hive debris. Of great importance also, was the success of the method in detecting SHB in debris collected from naturally infested hives from the USA.

Real-time PCR $C_{T}$ values for SHB DNA extractions in naturally infested hives were relatively consistent across samples showing the method to be efficient at extracting $A$. tumida DNA. Also, in spiked samples, when the amount of beetle tissue in hive debris was plotted against real-time $C_{T}$ values obtained for detection, the resulting correlation curve indicated that most of the beetle tissue spiked into the hive debris was retrieved during the extraction procedure. The consistency in extraction efficiencies was further demonstrated using a real-time PCR assay to detect the honey bee $18 \mathrm{~S}$ rRNA gene. There was enough background bee DNA in the hive debris, to allow good PCR amplification. In each experiment, the $C_{T}$ values for bee $18 \mathrm{~S}$ detection were all within 1 cycle showing that extraction efficiency was similar for all samples. It was concluded that the bee 18s rRNA assay is a suitable and reliable internal positive control to use for hive debris extractions.

Some decrease in real-time PCR detection sensitivity was observed in the spiked hive debris DNA extracts compared to the positive controls with no hive debris, this is most likely to be attributed to the presence of PCR inhibitors in the DNA extracts. In this study, clean-up procedures were not tested.

In summary, the method developed was shown to be successful in detecting SHB in spiked and naturally infested debris. The technology is directly transferable to other diagnostic laboratories with real-time PCR capabilities, and could therefore benefit overseas researchers and inspection/surveillance programmes, as well as legislative and government bodies, by providing the means to monitor, or test suspect hive samples for the presence of the SHB. There is scope to improve and refine the method further including the reduction of PCR inhibitors and increasing the volume of debris tested at any one time. In addition, the method needs further validation with more hive samples naturally infested with SHB to verify its reliability before large-scale use.

\section{ACKNOWLEDGEMENTS}

We are grateful to M. Allsopp (ARC Plant Protection Research Institute, Stellenbosch, South Africa) and M.T. Sanford (University of Florida, Institute of Food and Agricultural Sciences, Florida, USA) for providing SHB samples. Thanks also to the UK bee keepers for providing insect samples and to Panuwan Chantawannakul (Department of Biology, Faculty of Science, Chiang Mai University, Chiang Mai, Thailand) for providing the Tropilaelaps mite samples. Financial support was granted 
by Defra to the Central Science Laboratory and by an Emmy Noether fellowship of the DFG to PN.

Méthode basée sur l'ADN pour rechercher dans les débris de la colonie la présence du Petit coléoptère des ruches (Aethina tumida).

\section{Aethina tumida / parasite / Apis mellifera / dépistage / PCR en temps réel / méthodologie}

Zusammenfassung - Eine DNA-Methode zur Durchrasterung von Stockmüll auf die Präsenz des Kleinen Beutenkäfers (Aethina tumida). Ziel der gegenwärtigen Studie war die Entwicklung und Validierung eines schnellen Extraktionsprotokolls, das in Verbindung mit einem quantitativen PCR-Ansatz die artspezifische Erkennung des Kleinen Beutenkäfers (KBK) und seine Detektion im Stockmüll erlauben sollte. Wir gingen davon aus, dass angesichts der raschen Verbreitung des KBK ein schnelles und zuverlässiges Detektionsverfahren ein wertvolles Werkzeug in der KBK-Kontrolle darstellen könnte.

Das quantitative PCR-Verfahren wurde auf die Detektion des Cytochrom c-Oxidase I Gens von A. tumida angelegt. Zur Validierung wurden KBK-Eier, Larven und Imagines aus Afrika, Australien und Nordamerika eingesetzt. Das Verfahren wurde auch auf Kreuzreaktionen gegen die Milben Varroa destructor and Tropilaelaps clareae, sowie gegen eine Reihe an gängig in Stockmüll vorkommenden Insektenarten getestet. Es erwies sich als spezifisch für KBK und erlaubte die Detektion aller Stadien des Lebenszyklus und auch von KBK-Proben verschiedener geographischer Herkunft.

Anschliessend wurde das Verfahren auf die Erkennung von KBK in Stockmüllproben optimiert. Dazu wurde Stockmüll mit unterschiedlichen Mengen an Käfern und Larven versetzt und in Lysepuffer zermahlen. DNA wurde aus diesen Proben mittels eines automatisierten Verfahrens extrahiert, bevor die KBK-DNA-Menge dieser Proben im zuvor etablierten quantitativen PCR-Protokoll bestimmt wurde. Weitere Methodentests wurden mit natürlichen Stockmüllproben durchgeführt und mit Proben, denen KBK zugesetzt worden war. Die Ergebnisse zeigten, dass es möglich war, eine KBK-Menge von $17 \mathrm{mg}$ in einer Gesamtmenge von $30 \mathrm{~g}$ Stockmüll zu detektieren. Die Zuverlässigkeit der Extraktionsmethode wurde ebenfalls mittels quantitativer PCR getestet, und zwar für das $18 \mathrm{~S}$ rRNA Gen der Honigbiene, das ebenfalls aus Stockmüllproben amplifiziert werden konnte. Die $C_{T}$-Werte jedes Experiments lagen im Schwankungsbereich von je einem Zyklus, was darauf hinweist, dass die Effizienz des Extraktionsverfahrens für alle Proben ähnlich war. Die Amplifizierung des 18S rRNA-Gens stellt somit eine geeignete interne positive Kontrolle für die Stockmüllextraktion dar. Eine Verringerung der Sensitivität der PCR-Methode wurde in
DNA-Proben registiert, denen Stockmüll zugesetzt worden war, was auf die Anwesenheit von PCRInhibitoren in den DNA-Extrakten hinweist.

Wir stellen in dieser Arbeit ein Hochdurchsatzverfahren zur Detektion von KBK vor, das besonders dann von Nutzen sein kann, wenn ein KBK-Ausbruch an neuen Standorten zu verzeichnen ist. Das Verfahren kann noch weiter verfeinert werden, so dass noch grössere Probenvolumina gleichzeitig getestet werden können. Dies setzt allerdings eine weiter Validierung voraus. Die gegenwärtige Methode ist jedoch direkt einsetzbar und transferierbar für Forschungs- und Inspektionsund Überwachungsprogramme und stellt ein Mittel dar, KBK-verdächtige Stockproben zu testen.

Aethina tumida / quantitative PCR / Honigbiene / Kleiner Beutenkäfer / Stockmüll

\section{REFERENCES}

Ellis J.D. (2005) Reviewing the confinement of small hive beetles (Aethina tumida) by western honey bees (Apis mellifera), Bee World 86, 56-62.

Ellis J.D., Hepburn H.R. (2006) An Ecological digest of the Small Hive Beetle (Aethina tumida) a symbiont in honey bee colonies (Apis mellifera), Insectes Soc. 53, 8-19.

Evans J.D., Pettis J.S., Shimanuki H. (2000) Mitochondrial DNA relationships in an emergent pest of honey bees: Aethina tumida (Coleoptera: Nitidulidae) from the United States and Africa, Ann. Entomol. Soc. Am. 93, 415-420.

Evans J.D., Pettis J.S., Shimanuki H. (2002) Mitochondrial DNA relationships in an emergent pest of honey bees: Aethina tumida (Coleoptera Nitidulidae) from the United States and Africa, Ann. Entomol. Soc. Am. 93, 415-420.

Evans J.D., Pettis J.S., Hood W.M., Shimanuki H. (2003) Tracking an invasive honey bee pest: mitochondrial DNA variation in North American small hive beetles, Apidologie 34, 103-109.

Harman A. (2005) Small Hive Beetle, a review, Bee Culture, 39-41.

Hepburn H.R., Radloff S.E. (1998) Honey bees of Africa, Springer, and Berlin, Germany.

Hood W.M. (2004) The small hive beetle, Aethina tumida: a review, Bee World 85, 51-59.

Lundie A.E. (1940) The small hive beetle, Aethina tumida, Sci. Bull. 220, Union of South Africa, Department of Agriculture and Forestry, Pretoria, Transvaal Province.

Murilhas A.M. (2004) Aethina tumida arrives in Portugal. Will it be eradicated? Eurbee Newsletter 2, 7-9. 
Neumann P., Elzen P. (2004) The biology of the small hive beetle (Aethina tumida, Coleoptera: Nitidulidae): gaps in our knowledge of an invasive species, Apidologie 35, 229-247.

Neumann P., Härtel S. (2004) Removal of small hive beetle (Aethina tumida) eggs and larvae by African honey bee colonies (Apis mellifera scutellata), Apidologie 35, 31-36.

Spiewok S., Neumann P. (2006) Cryptic low-level reproduction of small hive beetles in honeybee colonies, J. Apic. Res. 45, 47-48.
Taber S., Hood M. (2000) Report on the South Carolina Hive Beetle experiment, Am. Bee J. 548549.

Ward L.I., Waite R., Boonham N., Fisher T., Brown M., Chantawannakul P., Taylor M., Thompson H., Bew M. (2007) First detection of Kashmir Bee Virus in the UK using real-time PCR, Apidologie 38, 181-190.

White B. (2004) Small hive beetle, Apiacta 38, 295301. 